\title{
Laboratory sampling according to triage - how much does it cost?
}

\author{
Ulf Martin Schilling ${ }^{*}$, Andreas Rönnersten \\ From Danish Society for Emergency Medicine: Research Symposium 2010 \\ Roskilde, Denmark. 20-21 May 2010
}

\section{Background}

METTS has been shown to be a triage-system reducing mortality at the emergency department. It was stated that point-of-care-analysis of standardized laboratory samples in triage systems could reduce the costs for single patients. In this single centre study, we controlled if the costs for single patients at the emergency department could be reduced by standardized sampling according to METTS without point-of-care analysis.

\section{Methods}

METTS was introduced as the triage system at our university hospital. The triage followed a standardized system following a user's guide, and standardized laboratory sample packages were created and taken accordingly. In contrast to the original concept using point-of-care-analysis, the samples were sent to the hospitals central laboratory.

The total costs for laboratory analysis during a three months period after the introduction of METTS at our emergency department were compared to their historical controls. The number of patients attended and the total costs for laboratory analysis were calculated according to the hospitals computerized attendance and accounting systems. Statistical analysis was performed using the unpaired two-tailed Student's T-test.

\section{Results}

A total of 9000 patients were attended from December 2008 to februari 2009 (period 1) and 8553 patients from December 2009 to februari 2010 (period 2, p = 0.39). Total costs for laboratory analysis was $439.3 \pm 53$ TSKR in period 1 and $670 \pm 21.6$ TSKR in period 2 $(\mathrm{p}=0.0089)$. Mean laboratory costs per patient were

\footnotetext{
* Correspondence: mschillingdeu@netscape.net

Department of accidents and emergencies, Linköpings university hospital, Sweden
}

$145.67 \pm 7$ SKR in period 1 and $235.33 \pm 5$ SKR $(\mathrm{p}<0.001)$ in period 2, i.e. $+61.55 \%$.

\section{Conclusion}

The introduction of standardized laboratory analysis using the hospitals central laboratory instead of pointof-care-systems results in significant increase of costs. Economically, the use of standardized sampling coupled to primary triage without point-of-care-analysis should be discouraged.

Published: 17 September 2010

doi:10.1186/1757-7241-18-S1-P19

Cite this article as: Schilling and Rönnersten: Laboratory sampling according to triage - how much does it cost? Scandinavian Journal of Trauma, Resuscitation and Emergency Medicine 2010 18(Suppl 1):P19.
Submit your next manuscript to BioMed Central and take full advantage of:

- Convenient online submission

- Thorough peer review

- No space constraints or color figure charges

- Immediate publication on acceptance

- Inclusion in PubMed, CAS, Scopus and Google Scholar

- Research which is freely available for redistribution

Submit your manuscript at www.biomedcentral.com/submit
C Biomed Central 